\title{
KELALAIAN BIROKRASI DAN KETIDAKADILAN PELAYANAN PUBLIK DI KANTOR DINAS KEPENDUDUKAN DAN PENCATATAN SIPIL KOTA PEKANBARU
}

\author{
Rodi Wahyudi \\ Dosen Fakultas Ekonomi dan Ilmu Sosial \\ Universitas Islam Negeri Sulthan Syarif Kasim Riau \\ email: rodi.wahyudi@uin-suska.ac.id
}

\begin{abstract}
Abstrak
Orang sering kecewa karena janji penyelesaian urusan mereka tidak dijaga. Pelayanan juga dipengaruhi oleh status sosial, semakin tinggi status sosial layanan semakin cepat. Penelitian ini bertujuan untuk menguji apakah masih ada birokrasi dan ketidakadilan dalam pelayanan publik? Jika masih membuktikan apa penyebabnya dan usaha apa yang bisa dilakukan untuk mengurangi perilaku buruk tersebut. Penelitian ini menggabungkan pendekatan kuantitatif dan kualitatif. Variabel Birokrasi Kelalaian terdiri dari 4 item dan variabel Ketidakadilan Birokrasi juga terdiri dari 4 item. Data diolah dengan menggunakan SPSS versi 20. Data dianalisis dengan menggunakan frekuensi dan uji deskriptif. Hasil analisis data kuantitatif diperdalam dengan data wawancara mendalam kepada informan kunci. Kuesioner penelitian telah diisi oleh 65 pegawai yang bekerja di Dinas Kependudukan dan Catatan Sipil Kota Pekanbaru. Hasil penelitian menunjukkan bahwa variabel kelalaian birokrasi tertinggi tidak dapat memberikan kepastian kapan waktu penyelesaian dokumen karena setiap perserikatan berhubungan dengan sub-bagian lainnya. Sedangkan variabel ketidakadilan birokrasi yang paling banyak adalah ketika pejabat keluarga / VIP datang untuk berhadapan, maka diberikan pelayanan khusus kepada mereka. Sifat alami juga akan menjadi bentuk jika tidak ada diskriminasi dalam pelayanan. Karyawan harus mengubah pola pikir bahwa melayani masyarakat juga merupakan sholeh amal sebagai badan amal keagamaan lainnya.
\end{abstract}

Kata Kunci: kualitas pelayanan publik, kelalaian birokrasi, ketidakadilan dalam pelayanan publik

\section{PENDAHULUAN}

Melindungi segenap bangsa Indonesia dan seluruh tumpah darah Indonesia dan untuk memajukan kesejahteraan umum, mencerdaskan kehidupan bangsa dan ikut melaksanakan ketertiban dunia yang berdasarkan kemerdekaan, perdamaian abadi dan keadilan sosial merupakan cita-cita mulia bangsa Indonesia. Pelayanan publik yang berkualitas merupakan bagian penting yang tidak dapat dipisahkan dari percepatan pembangunan negara. Cita-cita bangsa Indonesia tersebut tidak akan dapat tercapai tanpa birokrat yang profesional dan amanah.
Reformasi birokrasi telah dimulai sejak tahun 2006 bertujuan untuk mewujudkan pemerintahan meningkatkan kualitas Pelayanan publik. Secara umum, pendekatan yang dilakukan antara lain adalah peningkatan kompetensi pegawai, perbaikan sistem pengelolaan keuangan negara dan peningkatan produktivitas kerja aparatur sipil negara. Siddiquee \& Mohamed (2007) menyatakan bahwa ide reformasi birokrasi merupakan inisiatif yang secara eksplisit dilakukan untuk mencari cara yang lebih efektif dan efisien dalam memberikan pelayanan kepada masyarakat. Dalam laporan World Bank (2008) berjudul Public Sector Reform: 
What Works and Why? Menerangkan bahwa reformasi birokrasi merupakan agenda untuk perbaikan sistem administrasi dan perubahan arah kebijakan dalam meningkatkan daya saing negara. Kualitas pelayanan publik masih menjadi mimpi besar rakyat untuk segera diwujudkan oleh aparatur sipil negara di Indonesia. Kritikan terhadap buruknya kinerja birokrasi masih sering menjadi sorotan para peneliti di bidang administrasi negara. Birokrasi masih belum efektif dan efisien dalam memberikan pelayanan publik baik oleh pemerintah pusat maupun pemerintah daerah (Von Luebke, 2009).

Rakyat sering berhadapan dengan bayaran tidak resmi untuk mempercepat proses pelayanan. Secara keseluruhan, birokrasi terus dicirikan oleh proses tidak transparan, institusi kekurangan dana, pegawai tidak kompeten dan perilaku korupsi serta administrasi yang menyusahkan masyarakat (Synnerstrom 2007). Reformasi birokrasi diharapkan mampu mengurangi perilaku maladministrasi birokrasi. Reformasi sektor publik harus diawali dengan menanamkan aspek integritas diri dan profesional sehingga menjadi budaya organisasi birokrasi. Hasil kajian Ombudsman Republik Indonesia (2013) di Kota Pekanbaru yang mengukur tentang tingkat kepatuhan Satuan Kerja Perangkat Daerah pemerintah Kota Pekanbaru terhadap undang-undang pelayanan publik menunjukkan bahwa tingkat kepatuhan kantor pemerintah terhadap undang-undang pelayanan publik masih rendah. Hasil survey menyebutkan bahwa hanya 31,2\% kantor yang menggunakan sistem layanan terpadu, hanya $25,0 \%$ kantor yang memajang/ mengumumkan dasar hukum penyelenggaraan pelayanan, hanya 37,5 \% kantor yang memajang informasi mengenai persyaratan pelayanan, hanya $25,0 \%$ kantor yang mengumumkan jangka waktu penyelesaian pelayanan, hanya 18,8 \% kantor yang mengumumkan rincian biaya pelayanan dan hanya 25,0 \% kantor yang di ruang tunggunya dilengkapi dengan nomor antrian.

Dalam Undang-Undang Nomor 25 Tahun 2009 tentang pelayanan publik telah dinyatakan mengenai standar pelayanan termasuk jaminan kepastian waktu (pasal 15) dan penekanan aspek keadilan pelayanan (pasal 4). Namun kenyataan di kantor pemerintah masih dijumpai masyarakat yang mengeluh karena janji penyelesaian urusan sebagaimana disebut dalam standar pelayanan publik tidak terlaksana. Walaupun hal tersebut barangkali hanya perkara kecil, tetapi ketidakpuasan masyarakat atas pelayanan akan menjadi indikator kegagalan dalam reformasi birokasi dalam perbaikan pelayanan publik. Penelitian ini bertujuan untuk meneliti benarkah masih terjadi kelalaian birokrasi dan ketidakadilan dalam pelayanan publik?. Jika terbukti masih terjadi apakah faktor penyebabnya dan apa usaha yang bisa dilakukan untuk mengurangi perilaku buruk tersebut.

\section{Kualitas Pelayanan Publik}

Konsep kualitas pelayanan publik telah lama dikembangkan oleh para ilmuan. Pasuraman et al. (1985) merupakan salah satu pakar yang banyak menyumbang kepada pengembangan teori pelayanan publik. Beliau membangun model SERVQUAL yang berisi tentang ciri kualitas pelayanan yaitu kompetensi, pelayanan prima, kepercayaan, komunikasi yang santun, keselamatan, kemudahan persyaratan serta memahami kehendak masyarakat. Kualitas pelayanan sebagai penilaian sikap yang berkenaan dengan keunggulan suatu layanan dan merupakan tanggapan dari penilaian kualitas pelayanan tersebut. Zeithaml et al. (1990) pula menyatakan bahwa pelayanan berkualitas merupakan jalinan hubungan erat dan semangat setia kawan dalam memenuhi cita rasa dan kehendak pelanggan melalui kualitas pelayanan yang ditawarkan.

Ahmad Sutarji (1991) pula menekankan pentingnya kualitas pelayanan di kantor pemerintah agar dapat memuaskan hati rakyat yang menjadi 
pelanggan mereka. Parasuraman et al. (1993) menyatakan bahwa kepuasan terhadap kualitas pelayanan berkaitan dengan harapan warga negara terhadap kemampuan pegawai dalam melayani urusan rakyat dengan komitmen tinggi. Pendapat diatas turut didukung oleh Scheuing \& Christoper (1993) bahwa pelayanan yang berkualitas hanya akan dapat diwujudkan apabila terdapat sistem yang mengutamakan kepentingan warga. Fokus kepada kepentingan warga merupakan hal yang mutlak dilakukan oleh setiap unit pelayanan. Pelayanan berkualitas mampu memenuhi harapan dan keinginan masyarakat. Kunci agar dapat menciptakan pelayanan berkualitas dalam suatu organisasi adalah harus mampu mengimplementasikan prinsip-prinsip utama dalam pelayanan. Ada beberapa prinsip utama dalam mewujudkan pelayanan berkualitas yaitu pertama, kepemimpinan yaitu strategi pengurusan pimpinan dalam mengarahkan organisasi dalam peningkatan prestasi kerja pegawai. Kedua, pendidikan yaitu semua pegawai organisasi mendapatkan pendidikan dan latihan untuk meningkatkan tingkat kompetensi. Ketiga, strategi perencanaan yaitu perencanaan harus memcakup pengukuran dan tujuan organisasi untuk mencapai visi dan misinya. Keempat, kajian yaitu satu alat yang paling efektif untuk melakukan evaluasi agar jelas aspek mana yang dari perilaku organsisasi yang perlu diubah dalam upaya mewujudkan kualitas pelayanan. Kelima, komunikasi yaitu strategi organisasi dalam aspek komunikasi organisasi, baik sesama pegawai, pelanggan dan antar organisasi. Keenam, penghargaan dan hukuman merupakan aspek penting dalam pelaksanaan kualitas.

Menurut Mohammad Abbas (2001), antara ciri pelayanan yang baik ialah berawal dari birokrat yang berkelayakan dan berkualitas dimana mempunyai kompetensi, adil dan juga mengamalkan nilai dan kode etik dalam pekerjaan. Muhammad Uthman El-Muhammady
(2001) pula menerangkan bahwa dalam bekerja di kantor pemerintah seorang pegawai haruslah mempunyai nilai murni yang dapat mengurus masyarakat dengan baik dimana melalui pelayanannya hak masyarakat ditunaikan dan bertanggungjawab memastikan rakyat mendapat apa yang mereka perlukan.

Menurut Abdullah Bin Mohd Salleh (1979) seorang pegawai yang memiliki kesedaran diri yang baik tidak akan senang hati membuat kerja pada tahap minimal bahkan berusaha mencapai tahap semaksimal mungkin. Sebaliknya ia akan mencoba berupaya memenuhi waktu di kantor, bahkan bersedia bekerja di luar waktu kantor demi menyelesaikan pekerjaan berkaitan dengan pelayanan kepada rakyat. Ia sentiasa menjaga waktu supaya tidak terbuang dan menepati janji dalam segala tindakannya. Seorang pegawai yang memiliki kesedaran diri sentiasa menunjukkan inisiatif untuk memecahkan sesuatu masalah. Ia tidak hanya menunggu arahan yang datang dari pimpinan. Ia menggunakan kebijaksanaanya untuk memikirkan penyelesaian setiap masalah dan membuat keputusan dengan bijaksana. Sifat kesedaran diri ini patut ada pada setiap pegawai tanpa melihat pangkat dan golongannya.

\section{TINJAUAN PUSTAKA \\ Konsep Maladministrasi Birokrasi}

Perilaku maladministrasi birokrasi dapat dikatakan sebagai kegagalan teori birokrasi menjelaskan fungsi pegawai dalam mengurus urusan rakyat, kurang inisiatif dan tidak memiliki sifat tanggungjawab. Kajian mengenai fenomena maladministrasi birokrasi pertama sekali dijalankan oleh Hayward pada tahun 1917 yang menulis hasil kajiannya dalam buku professionalism and originality. Hayward (1917) menjelaskan bahwa sejak pekerjaan sebagai pegawai pemerintah termasuk dalam kategori pekerja profesional, maka seseorang yang bekerja dalam institusi birokrasi dituntut 
untuk bekerja dengan profesional dan bertanggungjawab. Aparatur sipil negara merupakan pelaksana tujuan negara dan mereka dibayar gaji oleh negara.

Kelalaian birokrasi dalam menyelesaikan urusan masyarakat termasuk dalam jenis perilaku maladministrasi birokrasi. Begitu juga ketidakadilan dalam pelayanan, membeda-bedakan orang lain dalam pelayanan, lebih mendahulukan orang kaya daripada orang miskin, lebih mengutamakan pejabat daripada rakyat biasa termasuk perilaku maladministrasi birokrasi. Secara etimologis Ahmad Basuki (2011) menyatakan bahwa maladministrasi berasal dari bahasa latin, mal berarti buruk atau jahat dan administrare artinya melayani. Birokrasi pula bermakna kantor pemerintah. Dengan demikian maladministrasi birokrasi membawa maksud pelayanan yang buruk atau kejahatan dilakukan oleh pegawai pemerintah. Maladministrasi birokrasi merupakan perbuatan tidak adil, tidak disiplin, tidak memberi contoh, kejahatan, perilaku buruk dalam proses pelayanan oleh pegawai pemerintah. Secara mudah maladministrasi birokrasi dapat diartikan sebagai kegagalan dalam memberikan pelayanan kepada masyarakat. Maladministrasi menurut Undang-Undang Ombudsman Republik Indonesia adalah perilaku atau perbuatan melawan hukum, melampaui wewenang, menggunakan wewenang untuk tujuan lain dari yang menjadi tujuan wewenang tersebut, termasuk kelalaian atau pengabaian kewajiban hukum dalam penyelenggaraan pelayanan publik yang dilakukan oleh penyelenggara negara dan pemerintahan yang menimbulkan kerugian materiil dan/atau immateriil bagi masyarakat dan orang perseorangan (Pasal 1 ayat 3 ).

Peters (2003) telah menjelaskan jenis perilaku maladministrasi birokrasi di Amerika Serikat. Ia telah menulis jenis perilaku maladministrasi birokrasi yaitu mencuri barang kantor, penyalahgunaan waktu di tempat kerja, korupsi, penyalahgunaan wewenang di kantor, konflik kepentingan, rendah kompetensi dari aspek teknikal dan kemampuan menejerial yang lemah. Cope (1997) menyatakan bahwa beberapa faktor sebagai 4 penyebab maladministrasi birokrasi yaitu korupsi dan rendahnya integritas, konflik dalam internal birokrasi, konflik antar kaum/etnik, tidak ada sifat disiplin dan buruknya hubungan antar pegawai.

Eklund \& Wimelius (2008) menyatakan bahwa maladministrasi birokrasi akibat tidak jelas sasaran yang ingin dicapai, tidak ada indikator dalam mengukur prestasi pelayanan, melakukan beberapa pekerjaan sekaligus tanpa berpegang kepada prinsip keutamaan dan tidak melakukan eksperimen sebagai usaha memperbaiki kualitas pelayanan dan tidak mau meninggalkan program yang sia-sia dan tidak memberi manfaat kepada pegawai atau masyarakat. Cheung (2001) telah merincikan beberapa bentuk maladministrasi birokrasi yang biasa berlaku dalam kalangan pegawai yaitu sikap tidak mau memberikan pelayanan kepada masyarakat, mementingkan diri sendiri dan berusaha untuk menunjukkan sifat sebagai penguasa, tidak ada sistem penilaian untuk mengevaluasi pekerjaan pegawai, perbaikan yang disampaikan tidak diterima oleh birokrasi pemerintah dan terlalu mengutamakan keuntungan peribadi.

\section{METODOLOGI PENELITIAN}

Penelitian ini menggabungkan pendekatan kuantitatif dan kualitatif. Variabel Kelalaian Birokrasi terdiri dari 4 item dan variabel Ketidakadilan. Birokrasi juga terdiri dari 4 item. Data diolah menggunakan software SPSS versi 20. Data dianalisis menggunakan uji frekuensi dan deskriptif. Hasil analisis dari data kuantitatif diperdalam dengan data wawancara secara mendalam kepada key informan sebanyak 2 orang. Angket penelitian telah diisi oleh 65 pegawai yang bekerja di Kantor Dinas Kependudukan dan Pencatatan Sipil Kota Pekanbaru. 


\section{HASIL DAN PEMBAHASAN}

Tabel 1 dibawah ini akan menunjukkan karakteristik responden yang diteliti yakni sebagai berikut.

\section{Tabel 1.}

Demografi Responden

\begin{tabular}{llcc}
\hline Demografi & & N & \% \\
\hline Jenis Kelamin & Laki-laki & 31 & 47,7 \\
Umur & Perempuan & 34 & 52,3 \\
& Umur 30 tahun ke & 33 & 50,8 \\
& bawah & 11 & 16,9 \\
& Umur 31-40 tahun & 16 & 24,6 \\
& Umur 41-50 tahun & 16 & 5,7 \\
Lama Bekerja & Umur 51 tahun ke atas & 5 & 7,7 \\
& Bekerja 10 tahun ke & 42 & 64,6 \\
& bawah & 10 & 15,4 \\
& 11-20 tahun & 13 & 20,0 \\
Status Pekerjaan & Aparatur Se atail Negara & 39 & 60,0 \\
& Pegawai Honorer & 26 & 40,0 \\
& Jumlah & $\mathbf{6 5}$ & $\mathbf{1 0 0 , 0}$ \\
\hline
\end{tabular}

Berdasarkan Tabel 1 diketahui bahwa pegawai laki-laki sebanyak 31 orang $(47,7 \%)$ dan perempuan sebanyak 34 orang $(52,3 \%)$. Responden berumur 30 tahun ke bawah sebanyak 33 orang $(50,8 \%)$, umur 31-40 tahun sebanyak 11 orang (16,9\%), umur 41-50 tahun sebanyak 16 orang $(24,6 \%)$ dan umur 51 tahun ke atas sebanyak 5 orang $(7,7 \%)$. Berdasarkan lama bekerja di kantor Disducapil, responden bekerja 10 tahun ke bawah adalah yang paling ramai yaitu 42 orang $(64,6 \%)$ berbanding responden yang bekerja 11-20 tahun yang hanya 10 orang $(15,4 \%)$ dan bekerja 21 tahun ke atas hanya 13 orang (20,0\%). Responden yang berstatus sebagai aparatur sipil negara sebanyak 39 orang $(60,0 \%)$ dan pegawai honorer sebanyak 26 orang $(40,0 \%)$.

\subsection{Kelalaian Birokrasi Dalam Pelayanan \\ Tabel 2 di bawah menunjukkan} bahwa dengan menggunakan uji deskriptif variabel kelalaian birokrasi yang nilai mean paling tinggi adalah item KB3 (Saya tidak bisa memberikan kepastian kapan waktu selesainya suatu dokumen karena setiap urusan berkaitan dengan sub-bagian lain di kantor ini) dengan nilai mean=3,10. Hasil analisis data menunjukkan bahwa pegawai di kantor Dinas Kependudukan dan Pencatatan Sipil masih belum melaksanakan amanah dalam undangundang pelayanan publik yang mengharuskan setiap unit pelayanan memberikan kepastian berapa lama waktu dalam menyelesaikan setiap urusan.

\section{Tabel 2.}

\section{Uji Deskriptif Kelalaian Birokrasi} Dalam Pelayanan Publik

\begin{tabular}{|c|c|c|}
\hline Item & Pernyataan & Mean \\
\hline KB 1 & 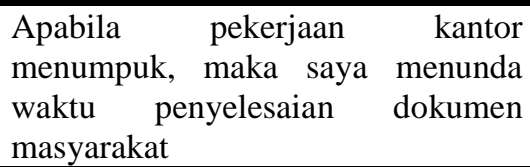 & 1,83 \\
\hline KB2 & $\begin{array}{l}\text { Jika saya mengulur waktu dalam } \\
\text { menyelesaikan urusan masyarakat, } \\
\text { maka saya selesaikan dengan segera }\end{array}$ & 3,10 \\
\hline KB3 & $\begin{array}{l}\text { Saya tidak bisa memberikan } \\
\text { kepastian kapan waktu selesainya } \\
\text { suatu dokumen karena setiap urusan } \\
\text { berkaitan dengan sub-bagian lain di } \\
\text { kantor ini }\end{array}$ & 3,47 \\
\hline KB4 & $\begin{array}{l}\text { Apabila saya lalai menyelesaikan } \\
\text { urusan masyarakat di kantor ini, } \\
\text { maka } \\
\text { memakluminya }\end{array}$ & 2,13 \\
\hline
\end{tabular}

Selama kajian dijalankan, maka penulis menyimpulkan bahwa kelalaian birokrasi disebabkan oleh beberapa faktor. Pertama, panjangnya rantai birokrasi. Masyarakat yang ingin mengurus akte kelahiran anak, mereka terlebih dahulu harus mendapat surat pengesahan kelahiran dari ketua rukun tetangga. Padahal sebenarnya surat pengesahan kelahiran dari klinik/rumah sakit tempat melahirkan sudah mencukupi. Menurut informan yang peneliti wawancarai tujuan surat pengesahan dari dari Ketua Rukun Tetangga (RT) atau Ketua Rukun Warga (RW) adalah karena merekalah yang paling banyak mengetahui tentang apa berlaku di kawasan masyarakat yang mereka pimpin. Kenyataan di lapangan seringkali masyarakat susah menjumpai pak RT karena beliau juga memiliki kesibukan lain. Kedua, kelalaian birokrasi disebabkan oleh hubungan antar unit dalam satu kantor bahkan kadangkala 
melibatkan beberapa kantor sebelum dokumen diluluskan. Contohnya, untuk mengurus kartu tanda penduduk, persyaratan yang mesti disiapkan oleh masyarakat adalah surat pengantar dari ketua rukun tetangga/ketua rukun warga, surat pengesahan dari kantor kelurahan, disahkan dikantor camat, verifikasi data di pejabat unit pelaksana teknis daerah Dinas Kependudukan dan Pencacatan Sipil. Apabila semua syarat lengkap, maka pegawai Dinas Kependudukan dan Pencacatan Sipil akan mulai memproses permohonan masyarakat tersebut. Pengurusan e-KTP lambat disebabkan oleh tidak cukupnya blanko, sedangkan blanko tersebut dikirim dari pusat. Walaupun sebenarnya kantor yang bertanggungjawab mencetak e-KTP adalah Dinas Kependudukan dan Pencacatan Sipil, tetapi masyarakat harus berurusan terlebih dahulu yang melibatkan beberapa kantor pemerintah.

Berdasarkan Peraturan Daerah Kota Pekanbaru nomor 5 tahun 2008 bahwa permohonan KTP dan akte kelahiran anak selesai dalam waktu 14 hari. Namun kenyataannya, masyarakat harus menunggu hingga 3 bulan. Hal ini terbukti ketika peneliti mewawancarai seorang warga yang peneliti temui sedang berurusan di kantor Dinas Kependudukan dan Pencacatan Sipil untuk mendapatkan akte kelahiran anak beliau. Peneliti sendiri ketika mengurus akte kelahiran anak memerlukan waktu lebih dari 14 hari kerja.

Kelalaian birokrasi menyelesaikan urusan masyarakat seolah-olah merupakan satu kesengajaan. Dari sinilah peluang besar bagi birokrat untuk menerima uang (gratifikasi) dengan cara menjanjikan kepada masyarakat bahwa urusannya akan selesai lebih cepat jika sanggup membayar lebih. Agus Dwiyanto et.al (2008) juga telah membuktikan dalam penelitiannya di Provinsi Sumatera Barat, Yogyakarta dan Sulawesi Selatan bahwa kelalaian pelayanan merupakan peluang untuk melakukan pungutan liar (pungli) dengan cara meminta masyarakat membayar uang lebih supaya urusannya dapat diselesaikan lebih cepat.

Faktor ketiga, kelalaian birokrasi disebabkan oleh kesalahan masyarakat sendiri. Mereka tidak melengkapi syarat seperti mana yang telah ditetapkan oleh kantor pemerintah. Permohonan masyarakat tidak akan diproses selagi syarat yang diminta belum lengkap. Misalnya untuk mendapat akte kelahiran anak, maka syarat yang harus dilengkapi adalah fotokopi KTP suami dan istri, kartu keluarga, fotokopi KTP 2 orang saksi atas kelahiran anak, pengesahan kelahiran dari klinik/rumah sakit tempat bersalin, surat pernikahan suami dan istri, surat pengesahan kelahiran dari ketua rukun tetangga dan surat pengesahan kelahiran dari kantor kelurahan dan disahkan oleh pegawai kecamatan. Masyarakat yang tidak membawa syarat yang diperlukan disebabkan karena mereka tidak mengetahui sehingga urusan mereka menjadi tertunda.

Kelalaian birokrasi merupakan ciri pelayanan yang tidak berkualitas. Apa yang diharapkan agar ciri pelayanan publik berkualitas masih belum dilaksanakan oleh pegawai. Sebaiknya pegawai menggunakan waktu dengan sebaiknya dan berusaha menyiapkan kerja dalam waktu yang telah ditetapkan. Melakukan kerja dengan sempurna, tidak mengharapkan balasan orang lain dan merasa bersalah jika tidak dapat menyempurnakan tugas sebagaimana yang ditetapkan. Bekerja tanpa rasa bosan serta bersedia menjalankan tugas yang dipertanggungjawabkan. Mengutamakan kepentingan tugas daripada kepentingan diri dan sanggup berkorban waktu dan tenaga demi kepentingan pelayanan, disamping mengamalkan sikap tolong menolong terhadap kebaikan dan menghindarkan diri dari perbuatan buruk.

Mengapa kelalaian birokrasi di Dinas Pendudukan dan Pencatatan Sipil masih sering dijumpai?. Penyebabnya adalah karena terdapat pegawai di kantor tersebut pegawai yang tidak kompeten dalam bekerja. Mereka masih belum mampu 
bekerja dalam tahap yang maksimal, lambat dan kurang memiliki sifat empati kepada masyarakat. Hasil wawancara peneliti dengan kepala Dinas Pendudukan dan Pencatatan Sipil bahwa faktor penyebab kelalaian birokrasi adalah masih belum ada dalam fikiran pegawai di Dinas Pendudukan dan Pencatatan Sipil untuk menyegerakan dan memudahkan urusan masyarakat, belum ada rasa malu jika sekiranya masyarakat datang berulang-kali ke kantor dalam keadaan urusan mereka belum selesai. Sifat yang masih menonjol adalah kurang ramah dan melambatlambatkan urusan. Rendahnya tingkat kesejahteraan pegawai di kantor juga faktor penyebab mereka tidak mampu bekerja dengan semangat. Sudah menjadi fitrah manusia bahwa mereka menginginkan kesejahteraan hidup dan salah satu indikator yang menunjukkan kebahagiaan hidup manusia adalah terpenuhi keperluan pokok seperti makan-minum, rumah, pakaian, kenderaan, pendidikan. Untuk memenuhi keperluan hidup tersebut manusia bekerja untuk mendapatkan sejumlah uang. Begitu juga pegawai, mereka juga manusia biasa yang ingin hidup layak seperti manusia lain. Namun, aspek kesejahteraan pegawai masih kurang diberi perhatian oleh pemerintah.

Di kantor Disdukcapil terdapat 2 jenis pegawai yaitu PNS dan honorer. Pegawai honorer adalah pegawai yang bekerja untuk menutupi kekurangan staf yang ada di kantor pemerintah. Mereka dibayar gaji harian yaitu Rp 66.000 per hari. Dalam sebulan mereka bekerja selama kurang lebih 20 hari, sehingga dalam sebulan mereka menerima gaji $\mathrm{Rp} 1.320 .000$. Mereka tidak mendapat uang tambahan seperti tunjangan rumah dan tunjangan jabatan seperti yang diperoleh oleh Pegawai Negeri Sipil (PNS). Pegawai honorer yang diterima bekerja di kantor pemerintah biasanya mereka yang ada hubungan keluarga dengan pihak atasan. Mereka diterima bukan atas dasar kompetensi dan profesionalisme.
Jika kelalaian birokrasi dilakukan oleh pegawai honorer, hal itu disebabkan karena mereka menyesuaikan dengan budaya kerja yang sudah ada di kantor tersebut. Kelalaian birokrasi bukanlah semata-mata atas kesalahan pegawai honorer tetapi juga memang karena budaya birokrasi sudah terbiasa dengan kerja lambat. Pegawai honorer bekerja mengikut arahan daripada pihak atasan. Sebenarnya pegawai negeri sipil adalah yang paling bertanggungjawab karena mereka yang menentukan suatu dokumen diluluskan atau tidak, disegerakan atau ditangguhkan.

\subsection{Ketidakadilan Birokrasi Dalam Pelayanan \\ Berikut ini peneliti tampilkan pada} tabel 3 hasil uji deskriptif ketidakadilan birokrasi dalam pelayanan publik.

Tabel 3.

\section{Uji Deskriptif Ketidakadilan Birokrasi Dalam Pelayanan Publik}

\begin{tabular}{|c|c|c|}
\hline Item & Pernyataan & Mean \\
\hline TA1 & $\begin{array}{l}\text { Apabila saya melayani urusan } \\
\text { masyarakat, maka saya duhulukan } \\
\text { sesuai dengan status sosial mereka }\end{array}$ & 1,35 \\
\hline TA2 & $\begin{array}{l}\text { Jika yang datang berurusan adalah } \\
\text { keluarga atau teman, maka tidak } \\
\text { harus memenuhi semua syarat dan } \\
\text { prosedur }\end{array}$ & 1,33 \\
\hline TA3 & $\begin{array}{l}\text { Apabila keluarga pejabat/VIP } \\
\text { datang berurusan, maka wajar saya } \\
\text { memberikan pelayanan khusus } \\
\text { kepada mereka }\end{array}$ & 1,90 \\
\hline TA4 & $\begin{array}{l}\text { Jika orang kaya datang berurusan, } \\
\text { maka saya memberikan pelayanan } \\
\text { istimewa kepada mereka }\end{array}$ & 1,27 \\
\hline
\end{tabular}

Tabel 3 di atas menunjukkan bahwa nilai mean yang paling tinggi dari uji deskriptif variabel ketidakadilan birokrasi adalah item TA3 (Apabila keluarga pejabat/VIP datang berurusan, maka wajar saya memberikan pelayanan khusus kepada mereka) dengan nilai mean $=1,90$. Bagaimana bentuk pelayanan yang diberikan adalah bergantung kepada siapa yang dilayani. Yang paling beruntung berurusan adalah pejabat atau keluarga pejabat. Bagaimana nasib rakyat biasa jika datang berurusan?. Apakah mereka 
mendapat pelayanan khusus seperti yang diberikan kepada very infortant person (VIP)?.

Secara teoritis, pelayanan publik berkualitas dapat diukur pada waktu terjadinya hubungan yang baik antara masyarakat dengan pegawai tanpa memandang status sosial sebagaimana yang ditulis Pasuraman et al. (1985) dan Zeithaml et al. (1990) masih jauh dari harapan jika pelayanan belum bersifat adil. Bagaimana cara agar bisa mengurangi pelayanan yang tidak adil?. Setiap kantor harus memiliki kounter untuk mendapat nomor antrian. Jika tidak ada nomor antrian, seseorang yang memiliki hubungan baik dengan pegawai kantor akan mendapat kemudahan dan didahulukan dalam proses pelayanan. Mereka bisa terus masuk dalam ruangan tanpa harus menunggu. Dalam Undangundang pelayanan publik telah jelas melarang adanya diskriminasi dalam pelayanan dan setiap kantor hendaknya menyediakan nomor antrian untuk mengelakkan ketidakadilan dalam pelayanan. Berdasarkan uji deskriptif (Tabel 4) menunjukkan bahwa fasilitas kantor yang tidak disediakan adalah tempat mengisi formulir (mean=1,55), kursi dan ruang tunggu mencukupi $($ mean=1,47) dan urusan mengikut nomor antrian (mean $=1,46)$.
Tabel 4.

Uji Deskriptif Fasilitas Kantor Yang Tidak Disediakan

\begin{tabular}{llc}
\hline Item & \multicolumn{1}{c}{$\begin{array}{c}\text { Fasilitas Kantor Yang Tidak } \\
\text { Disediakan }\end{array}$} & Mean \\
\hline FK1 & Kursi dan ruang tunggu mencukupi & 1,47 \\
\hline FK2 & Tempat parkir luas & 1,43 \\
\hline FK3 & Terdapat tempat mengisi formulir & 1,55 \\
\hline FK4 & $\begin{array}{l}\text { Terdapat contoh formulir yang telah } \\
\text { diisi }\end{array}$ & 1,40 \\
\hline FK5 & $\begin{array}{l}\text { Ada AC atau kipas angin di ruangan } \\
\text { tunggu }\end{array}$ & 1,41 \\
\hline FK6 & $\begin{array}{l}\text { Pelayanan menggunakan sistem } \\
\text { komputer }\end{array}$ & 1,18 \\
\hline FK7 & Tersedia sistem informasi pelayanan & 1,15 \\
\hline FK8 & Ruangan pelayanan telah disusun rapi & 1,06 \\
\hline FK9 & Urusan mengikut nomor antrian & 1,46 \\
\hline FK10 & $\begin{array}{l}\text { Kaunter dan ruangan dalam keadaan } \\
\text { bersih }\end{array}$ & 1,04 \\
\hline FK11 & Terdapat pengeras suara (mikrofon) & 1,13 \\
\hline FK12 & $\begin{array}{l}\text { Ada nomor telepon kantor yang bisa } \\
\text { dihubungi }\end{array}$ & 1,20 \\
\hline
\end{tabular}

Selagi usaha untuk mewujudkan keadilan birokrasi dalam pelayanan tidak diiringi oleh ketersediaan fasilitas yang memadai maka semakin sulit pelayanan yang adil dapat dicapai.Selain fasilitas, kunci utama penyebab ketidakadilan birokrasi adalah mindset pegawai. Hasil kajian Rodi Wahyudi (2015) membuktikan bahwa mindset merupakan satu set andaian, kaedah atau ulasan yang diyakini oleh seseorang cukup dominan mempengaruhi perilaku seseorang. Midnset erat hubungannya dengan falsafah hidup seseorang. Perubahan mindset seorang pegawai akan turut mempengaruhi perubahan dalam berpikir dan bertindak. Artinya mustahil akan terjadi perubahan perilaku pegawai selagi belum terjadi perubahan dalam mindset pegawai.

Sebuah cara berpikir seperti jika saya melayani pejabat dengan istimewa maka saya akan mudah jika ada urusan untuk promosi jabatan atau urusan naik pangkat. Inilah yang disebut dengan kerusakan sistem berfikir. Sepatutnya adalah siapapun yang datang diberikan pelayanan yang sama karena siapapun yang datang berurusan menginginkan apa diperlukan dapat dipenuhi dengan segera. 
Apabila birokrasi pemerintah mampu melaksanakan ciri pelayanan yang berkualitas maka mereka dapat selamat dari prasangka buruk masyarakat. Terdapat beberapa langkah yang dapat dilakukan agar kelalaian birokrasi dan ketidakadilan pelayanan dapat diminimalisir, yaitu:

1. Gunakan waktu dengan sebaiknya dan berusaha menyiapkan kerja dalam waktu yang telah ditetapkan.

2. Melakukan kerja dengan sempurna, tidak mengharapkan orang lain dan rasa bersalah jika tidak dapat menyempurnakan tugas sebagaimana yang ditetapkan.

3. Tidak memilih kerja serta tidak menunjuk-nunjuk dalam menjalankan tugas kepada atasan.

4. Patuh dan taat kepada peraturan serta berpegang teguh kepada ajaran agama di samping sentiasa menjaga harkat dan martabat diri dari perbuatan buruk dan keji.

5. Menjalankan tugas secara kolektif dan menyadari ide yang diperolehi secara bersama

6. Mengucapkan kata-kata yang baik dan bersopan santun dan sentiasa menjaga kebersihan diri, pakaian dan tempat kerja.

7. Bersedia menerima nasehat, arahan dan pendapat, bijaksana dalam membuat pertimbangan dan mudah memaafkan kesilapan orang lain.

8. Jangan menilai orang lain dari penampilan luar sehingga melanggar nilai keadilan.

\section{PENUTUP}

Pembangunan suatu negara akan berhasil apabila disokong oleh birokrasi yang kompeten, gesit, komitmen dan amanah. Kepuasan masyarakat yang datang berurusan akan wujud apabila janji menyelesaikan dokumen mereka sesuai dengan waktu yang telah ditetapkan dalam standar pelayanan publik. Sifat adil pula akan wujud jika tidak ada diskriminasi dalam pelayanan. Pegawai harus mengubah mindset bahwa melayani masyarakat juga merupakan perbuatan amal sholeh sebagaimana amal-amal agama lainnya.

\section{DAFTAR PUSTAKA}

Abdullah Bin Mohd Salleh. 1979. Panduan Perkhidmatan Cemerlang. Kuala Lumpur: Jabatan Perdana Menteri.

Agus Dwiyanto. 2008. Reformasi birokrasi publik di Indonesia. Yokyakarta: Gadjah Mada University Press.

Ahmad Basuki. 2011. Pertanggungan Jawab Pidana Pejabat Atas Tindakan Mal-Administrasi Dalam Penerbitan Izin Di Bidang Lingkungan. Jurnal Perspektif 16 (4): 252-258.

Ahmad Sutarji.1991. Perkhidmatan awam yang berkualiti.Penerbit INTAN Publications.

Cheung, A. B. L. 2001. Civil Service Reform in Post-1997 Hong Kong: Political Challenges, Managerial Responses?.International Journal of Public Administration, 24: 929-938.

Cope, G. H. 1997. Bureaucratic Reform and Issues of Political Responsiveness,Journal of Public Administration Research and Theory, 20:461-470.

Eklund, N., \& Wimelius, M. E. 2008.Globalization, Europeanization and Administrative Reform.Dalam J. Killian,\& N. Eklund. (Eds), Handbook of Administrative Reform. Boca Raton: Auerbach Publication.

Hayward, F. H. 1917. Professionalism and Originality. London: Allen \& Unwin.

Mohammad Abbas. 2001. Good Governence in Islam, http://www.irfi.org/articles/articles_ 351_400/good_governance_in _islam.htm, [24 Okt 2017].

Muhammad Uthman El-Muhammady. 2001. Pemilihan Dan Kepimpinan Dari Segi Politik Dan Dakwah. Kertas Kerja Seminar Etika dan Budaya Berpolitik dari Perspektif 
Islam, 25-26 September 2001 di Kuala Lumpur.

Ombudsman Republik Indonesia. 2013. Kepatuhan Pemerintah Daerah Kota Pekanbaru dalam Pelaksanaan UU 25 Tahun 2009 tentang Pelayanan Publik. Penerbit: Ombudsman Republik Indonesia Kantor Perwakilan Provinsi Riau.

Parasuraman, A., Valarie A.Zeithaml \& Leonard L. Berry. 1985. A Conceptual model service quality and its implications for future research. Journal of Marketing 49(4): 41-50.

Parasuraman, V. Zeithaml, A.,\& Beny, L.L. 1993.The nature and determinants of customer expectations of service.Journal of Academy of Marketing Science 21(1):1-12.

Peraturan Daerah Kota Pekanbaru nomor 5 tahun $2008 \quad$ Tentang Penyelenggaraan Administrasi Kependudukan.

Peter Carey.1986. Ekologi Kebudayaan Jawa dan Kita Kedung Kebo.Jakarta: Pustaka Azet.

Peters. 2003. Comparative Public Administration: The Essential Readings. Great Britain: Butterworth-Heinemann Ltd.

Rodi Wahyudi. 2015. Perilaku Maladministrasi Dalam Pelayanan Publik di Kota Pekanbaru Provinsi Riau: Faktor Penyebab dan Solusinya. Jurnal Administrasi Publik, Vol 12 (1): 55-70

Scheuing. Eberhard, E. Christopher, William F. 1993. The service quality handbook. New York : Amacom.

Siddiquee \& Mohamed Zein. 2007. Paradox of Public Sector Reform in Malaysia: A Good Governance Perspective.Public Administration Quarterly, 31(3): 40-55.

Synnerstrom, S. 2007. The civil service: towards efficiency, effectiveness and honesty in Indonesia: Democracy and the Promise of
Good Governance. Institute of Southeast Asian Studies: Singapore.

Undang-Undang Nomor 25 Tahun 2009 Tentang Pelayanan Publik.

Undang-Undang Nomor 37 Tahun 2008 Tentang Ombudsman Republik Indonesia.

Von,L., C. 2009. The political economy of local governance: findings from an Indonesian field study, Bulletin of Indonesian Economic Studies 45 (2): 20-30.

World Bank. 2008. Public Sector Reform: What Works and Why? Washington DC: World Bank Independent Evaluation Group.

Zeithaml, V.A., Parasuraman \& L.L.Berry. $\quad 1990 . \quad$ Delivering quality services :balancing customer perceptions and expectations. The Free Press, A Division of Macmillan Inc., New York. 